\title{
Towards a European Health Union - What Role for Member States?
}

\author{
Mary Guy
}

\begin{abstract}
Calls for a European Health Union apparently challenge long-standing beliefs that national healthcare system organisation is a Member State competence. Interaction between Member State and European Union (EU) levels therefore fundamentally requires reflection in the design, overall structure and legal basis of any European Health Union. Article 168(7) Treaty on the Functioning of the European Union (TFEU) provides the current version of the seemingly limited EU competence with regards to national healthcare system organisation and has received surprisingly little attention thus far. On the one hand, within the wider EU health competence 'web', Article 168(7) TFEU constrains EU adoption of measures incentivising Member States to use particular treatments or to increase intensive care units in response to COVID-19. On the other hand, Article I68(7) TFEU is challenged by the perceived influence of Country-Specific Recommendations issued in the context of the European Semester on national health policies. This opinion piece provides an original assessment of Article 168(7) TFEU to argue that Treaty change to redress the balance between EU and Member State competence regarding national healthcare systems may be uncalled for given both the flexibility afforded by the provision and the complexity and diversity of Member State healthcare systems.
\end{abstract}

\section{INTRODUCTION}

The COVID-19 pandemic is demonstrating clear benefits to coordination and cooperation at European Union (Union) level in tackling a global health crisis. The Socialists and Democrats (S\&D)'s call for a European Health Union emphasises the relative powerlessness of Member States to act individually in the face of the COVID-19 pandemic, and the damaging effects of having underfunded healthcare systems and differing healthcare capacities across the Union.' The S\&D's call is wide-ranging, encompassing aspects as diverse as access to pharmaceuticals, health research, and health and safety in the workplace, ${ }^{2}$ but appears premised on a fundamental need for more (or more explicit) Union-level cooperation because healthcare systems remain the responsibility of Member States.

Article 168(7) Treaty on the Functioning of the European Union (TFEU) provides that Member States have responsibilities for national health policy and healthcare system organisation and management, and that the Union must respect this. ${ }^{3}$ However, this provision

\footnotetext{
I Group of the Progressive Alliance of Socialists \& Democrats in the European Parliament, Letter from I. García Pérez, H. Fritzon and J. Gutteland to President von der Leyen, President Michel and Prime Minister Plenković. 7 May 2020. https://www.socialistsanddemocrats.eu/sites/default/files/2020-05/european-healthunion-letter-200507.pdf.

${ }^{2}$ S\&D, "A European Health Union - Increasing EU Competence in Health - Coping with COVIDI9 and Looking to the Future”, S\&D Position Paper, I 2 May 2020.

https://www.socialistsanddemocrats.eu/sites/default/files/2020-

05/european_health_union_sd_position_30512.pdf.

${ }^{3}$ Connections with national healthcare laws and practices of Article 35 Charter of Fundamental Rights of the European Union are not considered here.
} 
is considered to add little to the formal division of powers elsewhere in the Treaties, ${ }^{4}$ such that its constraining power on Union action may be considered primarily political, rather than legal. ${ }^{5}$ Narratives explaining national reluctance to cede power over healthcare systems to the Union level generally emphasise the latter's economic significance and socio-political consequence, as well as the prominence accorded to health, as distinct from other aspects of social policy. ${ }^{6}$ A seemingly logical consequence of this is that the Union's response appeared initially constrained by the present framework, which developed "because the Member States wanted it so". ${ }^{7}$

Current framing of Article 168(7) TFEU suggests it represents exclusively an impediment to Union action in combatting the COVID-19 pandemic, inhibiting the Union's ability to provide either comprehensive solutions to a complex and evolving situation, ${ }^{8}$ or a corrective to national policies governing COVID-19 responses. ${ }^{9}$ This contrasts sharply with a previous "counter-narrative" of Member State competence regarding national health policy and healthcare system organisation being challenged by wider Union action, notably in connection with Union-level fiscal policy and assessment of national economic policies. A specific example of this is the Country-Specific Recommendations (CSRs) ${ }^{10}$ issued by the Commission to Member States in the context of the annual European Semester cycle, intended to coordinate economic policies across the Union. This aspect of Union policy is examined here primarily for offering an additional perspective on Union-Member State interaction beyond considerations of the limited scope for harmonisation, which are examined elsewhere. "I

This paper seeks to clarify the role for Member States within a European Health Union by reference to the parameters of Article 168(7) TFEU and the "counter-narrative" associated with CSRs (Section II). It emerges that Article I68(7) TFEU may provide at best a porous barrier to Union-level intervention in national healthcare, ${ }^{12}$ and that it can be more correct

\footnotetext{
${ }^{4}$ S.L. Greer, N. Fahy, S. Rozenblum, H. Jarman, W. Palm, H.A. Elliott, M. Wismar, Everything You Always Wanted to Know about European Union Health Policies But Were Afraid To Ask, Second Edition, WHO/European Observatory on Health Systems and Policies, 2019, page 63.

${ }^{5}$ Consistent with wider considerations of Union ability to take action in health-related matters. See further K.P. Purnhagen, A. de Ruijter, M.L. Flear, T.K. Hervey, A. Herwig, "More Competences than You Knew? The Web of Health Competence for European Union Action in Response to the COVID-I9 Outbreak", (2020) European Journal of Risk Regulation, II, 297-306.

${ }^{6}$ See further, E. Brooks and A. de Ruijter, "Toward more comprehensive law and policy research", in EU Health Law and Policy - Shaping a Future Research Agenda, Health Economics, Policy and Law Special Issue, guest edited by E. Brooks and M. Guy (forthcoming).

${ }^{7}$ A. de Ruijter and S.L. Greer, "EU health law and policy in and after the COVID-19 crisis", (2020) European Journal of Public Health, I-2.

${ }^{8}$ S.L. Greer, "How did the EU get the Coronavirus so wrong? And what can it do right next time?", The New York Times, April 6, 2020.

${ }^{9}$ Disappointment having been expressed that the Union level could be a place to challenge national policies regarding COVID-19 intensive care guidelines potentially violating the rights of older and disabled patients. D.M.R. Townend, B. Wouters, R. van de Pas, E. Pilot, "What is the Role of the European Union in the COVID19 Pandemic?", Medicine and Law, June 2020.

${ }^{10}$ N. Azzopardi-Muscat et al., "EU Country-Specific Recommendations for health systems in the European Semester process: Trends, discourse and predictors", (2015) Health Policy II 9, 375-383. S. Garben,

"Supporting Policies", chapter 38 in (eds) Pieter Jan Kuiper, Fabian Ambtenbrink, Deidre Curtin, Bruno De Witte, Alison McDonnell, Stefaan Van den Bogaert, The Law of the European Union, Fifth Edition, Wolters Kluwer, 2018.

"For example, Purnhagen et al., supra, note 5.

${ }^{12}$ Art. 168 TFEU has been depicted as a gate in a field around which sheep representing EU policies as diverse as the internal market, agriculture and trade are free to roam. Greer et al., supra, note 4, page 176.
} 
to speak of an interconnected, even symbiotic, relationship between the Member State and Union levels.

These insights provide a basis for considering current national responses to the COVID-I9 pandemic (Section III). This prompts further questions of what national "health policy" means at present, including whether continuation of non-COVID-19 health services amounts to a sequential third response phase, or runs concurrently with the systematisation of phase I (the emergency) and phase 2 (relaxation of national risk responses). ${ }^{13}$ A further question is how the interconnected relationship between Member State and Union levels operates in each of these phases.

The analysis in this paper concludes that the role for Member States in a European Health Union by reference to Article 168(7) TFEU is significant. It is notable that the S\&D's call operates around Article 168(7) TFEU, as do other proposals ${ }^{14}$ for Union-level activity in tackling the pandemic henceforth. While this may be logical in view of the current framework, it nevertheless implies that Article 168(7) TFEU provides an important basis for building a European Health Union, or at least that this should offer a focal point to indicate the importance of addressing national health policy and healthcare system organisation and its interaction with Union-level activity. Making use of other aspects of Union policy such as the European Semester, as the S\&D's call suggests, could provide an important supplement to action taken in connection with the wider public health elements of Article I68 TFEU.

\section{NATIONAL HEALTH POLICY AND NATIONAL HEALTHCARE SYSTEM ORGANISATION: AN INTERCONNECTED RELATIONSHIP BETWEEN MEMBER STATES AND THE UNION}

\section{The parameters of Article 168(7) TFEU}

A "subsidiarity clause for healthcare" ${ }^{15}$ was introduced with the Maastricht Treaty, ${ }^{16}$ and underwent four subtle, but ultimately significant, amendments in its evolution to Article 168(7) TFEU: ${ }^{17}$ a decoupling of the subsidiarity focus on healthcare from "public health"; a change in Union focus from "fully respecting" to merely "respecting" Member State responsibilities; explicit stipulation of "health policy" alongside these; and elaboration, in a new second sentence, of what the responsibilities include.

\footnotetext{
${ }^{13}$ A. Alemanno, "The European Response to COVID-19: From Regulatory Emulation to Regulatory Coordination?", (2020) European Journal of Risk Regulation, II, 307-316.

${ }^{14}$ See, for example, Purnhagen et al. supra, note 5, and de Ruijter and Greer (2020), supra, note 7.

${ }^{15}$ L. Hancher and W. Sauter, EU Competition and Internal Market Law in the Health Care Sector, Oxford University Press, Oxford 2012., Paragraph I.27, page 10.

${ }^{16}$ Art. 152(5) Treaty on the European Union (TEU), which read "Community action in the field of public health shall fully respect the responsibilities of the Member States for the organisation and delivery of health services and medical care.[...]". It is noted that the original iteration of the Union public health Treaty competence - Art. 129 EC - did not include a subsidiarity element. For background to this provision, see T.K. Hervey and J.V. McHale, Health Law and the European Union, CUP 2004, pages 72-84, and Hervey and de Ruijter in this issue.

${ }_{17}$ All four changes appear to have taken place in the period between October 2003 and October 2004, according to drafts issued as part of CIG 4/03 (page 335-337 (article III-I79); 06.10.2003 and CIG 87 REV2/04 (page 217) (article III-279), 29.10.2004. The wording was retained in drafts from other discussions, notably CIG 2007 Lisbon.
} 
Article 168(7) TFEU thus reads:

"Union action shall respect the responsibilities of the Member States for the definition of their health policy and for the organisation and delivery of health services and medical care. The responsibilities of the Member States shall include the management of health services and medical care and the allocation of the resources assigned to them.[...]"

The framing of Article 168(7) TFEU has been considered to read as a mere elaboration of the extent of Member State competence, and indeed a clarification of the exclusive competence of Member States. ${ }^{18}$ However, the "downgrade" of Union action - to merely "respecting" Member State responsibilities - was considered already in $201 \mathrm{I}$ both "to leave open more room for [Union] involvement...", and to introduce "a delicate and sophisticated balance between the [Union] and national competences in health care." 19

Such "a delicate and sophisticated balance" and juxtaposition of the "statements of national autonomy" 20 of the second sentence of Article 168(7) TFEU can be illustrated - with the benefit of hindsight - by reference to Union fiscal policy reforms. It appears logical to suggest that Member States would have responsibility for resource allocation within national healthcare systems. However, "the allocation of resources assigned to them" may also be interpreted as Union activity influencing the (financial) resources assigned to the Member States, ${ }^{21}$ according to the level of fiscal oversight a Member State has been subject to following the 2008 economic crisis. This appears to support a long-standing consideration that "explicit stipulations... and implicit understanding of the subsidiarity principle...proved not to be the "guarantees" of no [Union] interference in national health care services that they were often held to be."22

This porousness of the apparent barrier of Article I68(7) TFEU enables a further conception of the interrelation between Union and national competence to emerge as an interconnected relationship, now illustrated by reference to Union fiscal policy.

\section{Article I68(7) TFEU and the CSRs of the European Semester}

The European Semester and its CSRs have been deemed "a particularly coercive form of soft law", ${ }^{23}$ with considerable impact on the policy space of national executive governments and parliaments. ${ }^{24}$ The CSRs have developed to cover health matters, both in terms of the actors

${ }^{18} \mathrm{~J}$-C Piris, The Lisbon Treaty - A Legal and Political Analysis. CUP 2010. Page 32I.

19 J.W. van de Gronden and E. Szyszczak, "Conclusions: Constructing a "Solid" Multi-Layered Health Care Edifice”, in eds. J.W. van de Gronden, E. Szyszczak, U. Neergaard, M. Krajewski, Health Care and EU Law, TMC Asser Press, 201 I. Page 486.

${ }^{20}$ Garben, supra, note 10.

${ }^{21}$ Whereby "them" equates to "Member States", not "the management of health services and medical care". Such ambiguity is arguably more evident in some language versions of Art. 168(7) TFEU (English and French) than others (German and Dutch).

${ }^{22}$ E. Mossialos, G. Permanand, R. Baeten and T. Hervey, "Health systems governance in Europe: the role of European Union law and policy”, Chapter I in (eds) E. Mossialos, G. Permanand, R. Baeten and T.K. Hervey, Health Systems Governance in Europe - The Role of European Union Law and Policy, CUP 20I0. Page I.

${ }^{23}$ S. Garben, "The Constitutional (Im)balance between "the Market" and "the Social” in the European Union", (2016) I 3 European Constitutional Law Review 23.

${ }^{24}$ F. Amtenbrink, "The Metamorphosis of European Economic and Monetary Union”, Chapter 28 in (eds) A. Armull and D. Chalmers, The Oxford Handbook of European Union Law, Oxford University Press 20I5. Page 744. 
involved, ${ }^{25}$ and, since 2018, in the Semester's role in delivering the European Pillar of Social Rights. The CSRs have been considered influential regarding national health policies, ${ }^{26}$ and the European Semester to mark a turning-point in Union approaches towards Member State competence regarding healthcare system organisation. ${ }^{27}$ This appears borne out by concerns about negative consequences for the accessibility of public healthcare in connection with the fiscal policies extending to Greece, Portugal and Ireland, ${ }^{28}$ and the intuition that Member State to determine national health policy (and indeed healthcare system organisation) becomes contingent (indirectly or directly) upon the fiscal policies they are obliged to engage with. ${ }^{29}$

However, it is possible to argue that the reality of healthcare-related CSRs may be more nuanced than a simple narrative of the Union telling Member States what to do regarding national health policy.

The idea that the interaction between Union and Member State levels may be more interconnected emerges when it is understood that the CSRs form an end stage of an assessment cycle involving both levels. ${ }^{30}$ Although some Member State involvement depends upon membership of the Eurozone, Country Reports provided by the Member States "feed into" the cycle and find reflection in the CSRs. For example, a 20I5 CSR issued to France exhorted the removal of restrictions on access to, and exercise of, regulated professions, in particular as regards the health professions. ${ }^{31}$ This appears controversial ${ }^{32}$ insofar as it may indicate Union-level endorsement of competition reforms in national healthcare, ${ }^{33}$ but arguably becomes less so when viewed against wider assessment cycles, and wider policy shifts in French healthcare: concerns about the numerus clausus principle restricting access to healthcare professions was referenced in the 201 I Country Report, ${ }^{34}$ and removal of the numerus clausus principle has been seen as a way to increase access to healthcare in line with the wider Ma Santé 2022 healthcare system reform package. A further example is proposals for competition reforms within the Irish healthcare system. These have also received varying amounts of attention at Union level - from explicit inclusion of removing restrictions to competition in medical services within structural reforms linked with the Economic

\footnotetext{
${ }^{25}$ Including commitment from DGSANTE, “European Semester: Health reforms need to continue". Health EU - Newsletter 236, June 2019. https://ec.europa.eu/health/eunewsletter/236/newsletter_en Further on the actors involved, see Greer et al., supra, note 4, pages I55-6.

${ }^{26}$ Azzopardi-Muscat et al., supra, note 10.

${ }^{27}$ S. Greer, H. Jarman and R. Baeten, "The New Political Economy of Health Care in the European Union: The Impact of Fiscal Governance”, (2016) 46(2) International Journal of Health Services, 262-282.

${ }^{28}$ Garben, supra, note 10.

${ }^{29}$ For an overview of the different mechanisms, see Greer et al., supra, note 4, pages 162-164.

${ }^{30}$ For a visual representation of the European Semester timeline, see

https://ec.europa.eu/info/sites/info/files/2018-european-semester-timeline_en.pdf

${ }^{31}$ https://eur-lex.europa.eu/legal-content/EN/TXT/PDF/?uri=CELEX:32015 H0818(I5)\&from=EN CSR 4.

Although not formulated as a CSR, these concerns had been articulated in 2012 as well. https://eurlex.europa.eu/legal-content/EN/TXT/PDF/?uri=CELEX:52012DC03 I3\&from=EN, paragraph I5.

${ }^{32}$ As a measure for reducing health expenditure, this CSR has also been considered to defy what is known about the importance about supply-induced demand in healthcare. See Greer et al., supra, note 4, page 165.

${ }^{33}$ For an indication of the issues involved in developing competition reforms in national healthcare by reference to the Union competition law framework, see M. Guy, Competition Policy in Healthcare - Frontiers in Insurance-Based and Taxation-Funded Systems, Intersentia 2019, Chapter 2.

${ }^{34}$ As mentioned in Preamble I5 France CSR 201 I (https://ec.europa.eu/info/publications/20I I-europeansemester-country-specific-recommendations-commission-recommendations en)
} 
Adjustment Programme, ${ }^{35}$ to referencing Sláintecare reforms to deliver universal healthcare in the 2019 CSRs, ${ }^{36}$ seemingly reflecting national shifts in emphasis.

Overall, it might be considered that challenges to Member State competence by CSRs under Article 168(7) TFEU lie more in the formalisation of national health policy entailing possible consequences for non-compliance, rather than "top-down" directions from the Union level. The interconnectedness between the national and Union levels vis-à-vis CSRs (if not other fiscal policy instruments) may suggest a flexibility and responsiveness from both levels. How this evolves as CSRs include both national and Union-level aspects regarding the overarching aim of addressing the COVID-I9 pandemic, ${ }^{37}$ as well as economic imbalances, remains to be seen.

\section{COVID-I9 RESPONSES: ALSO AN INTERCONNECTED RELATIONSHIP BETWEEN MEMBER STATES AND THE UNION?}

In COVID-19 responses, questions of Union-Member State interaction appears more in evidence regarding health policy, as opposed to healthcare system organisation. ${ }^{38}$ Whether an interconnected relationship is in evidence appears governed in part by how national "health policy" is defined, including considerations of factors with both Union-level aspects and potential for divergent Member State-level responses, ${ }^{39}$ such as social determinants of health ${ }^{40}$ and digitalisation. ${ }^{41}$

Insofar as it may be possible to characterise COVID-19 responses as "direct" and "indirect", this can offer further insights into symbiosis in the interaction between the Union and Member State levels, and where "more Union" may or may not be welcomed at a national level.

"Direct" COVID-19 responses can be seen with the systematisation of phases I (the emergency) and 2 (the relaxation of national risk responses). ${ }^{42}$ Within these phases, convergence of national policies has been identified, but deemed attributable more to a spontaneous regulatory emulation process than deliberate design. ${ }^{43}$ However, it is at the level of "direct" responses that most recommendations for greater (and temporary) Union-level

\footnotetext{
${ }^{35}$ For discussion, see DGECFIN, “The Economic Adjustment Programme for Ireland”, Occasional Papers 76, February 201 I. Page 66.

https://ec.europa.eu/economy_finance/publications/occasional_paper/20I I/pdf/ocp76_en.pdf

${ }^{36}$ https://eur-lex.europa.eu/legal-content/EN/TXT/PDF/?uri=CELEX:52019DC0507\&from=EN

${ }_{37}$ Already in evidence in the 2020 CSRs. https://ec.europa.eu/info/publications/2020-european-semestercountry-specific-recommendations-commission-recommendations en

${ }^{38}$ The latter apparently confined to the national level - for example, discussions among economists in the Netherlands of whether increased costs in responding to COVID-19 necessitate (or not) a fundamental system change away from the "managed competition" model formally introduced in 2006. P. Jeurissen, E. Adang, F. Kruse and N. Stadhouders, "Coronavirus kan de zorg structureel veranderen", ESB I05(4784) 168-I70, and in response, M. Varkevisser and E. Schut, "Kosten corona geven geen aanleiding om zorgstelsel fundamenteel te hervormen”, ESB 105(4785) 204-207.

${ }^{39}$ See individual responses the informative series: Health Economics, Policy and Law, HEPL blog series, Country Responses to the Covid 9 Pandemic. https://www.cambridge.org/core/journals/health-economics-policy-andlaw/hepl-blog-series-covid I9-pandemic.

${ }^{40}$ A. Reeves, "The EU and social determinants of health in a post-COVID world", (2020) European Journal of Public Health, 8 July 2020.

${ }^{41}$ For consideration of the effect of digitalisation on health policy more generally, see Brooks and de Ruijter, supra, note 6.

42 Alemanno, supra, note 13.

43 Ibid.
} 
intervention are pitched, ${ }^{44}$ and where "more Union" may be welcomed by Member States. "Direct" responses show how Union-level action may "respect" national competence and play a supportive role, thus indicating an overall interconnected relationship between the Union and Member State levels. For example, while the Union cannot determine increases in intensive care units, ${ }^{45}$ underlying Union frameworks may give effect to such national policies by facilitating access to these units in neighbouring Member States. ${ }^{46}$

"Indirect" COVID-19 responses, in contrast, primarily address continuity of non-COVID-19related healthcare at national levels alongside the pandemic response. ${ }^{47}$ As such, these may form a distinct phase - or perhaps a sequential phase 3 - to "direct" responses, and raise questions about the extent to which "more Union" may be welcome. Examples of "indirect" responses may include temporary government support (state aid) to implement e-health applications underpinning, inter alia, mental health and social support services in the Netherlands, ${ }^{48}$ or differing levels of cooperation with private sector providers, ${ }^{49}$ for example, in Portugal and Ireland, ${ }^{50}$ to ensure continuity of non-COVID-19-related health services as public health service provision is repurposed to focus on the pandemic.

These examples of "indirect" responses illustrate the interconnected relationship between the Member State and Union levels in determining applicability of Union competition law (i.e. the antitrust and state aid provisions). This can be broadly dependent on the degree of competition in a system, and exceptions to this, notably non-economic Services of General Economic Interest (SGEI), which are determined at Member State, rather than Union level. ${ }^{51}$ It is considered that a decision to engage with what might otherwise be considered marketisation reforms is indeed a national one in line with Article 168(7) TFEU, but entails the consequence of Union competition law becoming applicable. ${ }^{52}$ At present, Union competition law has been relaxed temporarily, ${ }^{53}$ and the aforementioned Dutch state aid case

\footnotetext{
${ }^{44}$ Notably in connection with "incentive measures" and Art. 168(5) TFEU. See Alemanno, supra, note 13, and Purnhagen et al., supra, note 5 .

${ }^{45}$ Purnhagen et al., supra, note 5.

${ }^{46}$ For example, Dutch patients having access to ICU beds in Germany. I. Wallenburg, P. Jeurissen, J-K. Helderman, R. Bal, "The Netherlands' Response to the Coronavirus Pandemic - Update (May 2020)", https://www.cambridge.org/core/blog/2020/04/06/the-netherlands-response-to-the-coronavirus-pandemic/. ${ }^{47}$ Addressing long-term health effects of COVID-19 may also merit consideration in this connection.

${ }^{48}$ As was recently approved in the state aid case, Case SA.57897 Covid-19: E-Health at home 2.0.

${ }^{49}$ This may also play a part in "direct" responses - for example supporting COVID-19 testing efforts, as noted in the Czech Republic. O. Löblová, "The Czech Republic's Response to the Coronavirus Pandemic" 22 May 2020. https://www.cambridge.org/core/blog/2020/04/07/the-czech-republics-response-to-the-coronaviruspandemicl.

${ }^{50}$ C. Mateus, "Portugal's Response to the Coronavirus Pandemic" 18 May 2020.

https://www.cambridge.org/core/blog/2020/04/07/portugals-response-to-the-coronavirus-pandemic/ S. Thomas, "Ireland's Response to the Coronavirus Pandemic", 15 May 2020. https://www.cambridge.org/core/blog/2020/04/06/irelands-response-to-the-coronavirus-pandemic/.

${ }^{51}$ Consolidated Version of the Treaty on European Union - Protocol (No. 26) on Services of General Interest. Official Journal II5, 09/05/2008 P. $0308-0308$.

${ }^{52}$ T. Prosser, "EU competition law and public services", Chapter 7 in (eds) E. Mossialos, G. Permanand, R. Baeten and T.K. Hervey, Health Systems Governance in Europe: The Role of European Union Law and Policy, Cambridge University Press, Cambridge 2010.

${ }^{53} \mathrm{C}$ II 6 I/7. 8.4.2020. European Commission, Communication from the Commission, Temporary Framework for assessing antitrust issues related to business cooperation in response to situations of urgency stemming from the current COVID-19 outbreak (2020/C 116 I/02). European Competition Network (ECN), "Antitrust: Joint statement by the European Competition Network (ECN) on application of competition law during the
} 
was decided in the context of the temporary framework. However, relaxation, even for an extended period, is a different proposition to a longer-term evolution of approach to determining an appropriate role for, and applicability of, Union competition law ${ }^{54}$ as "indirect" responses may extend beyond "temporary", and even take on a more permanent character. While recent calls for solidarity ${ }^{55}$ may find expression in questions of the applicability of Union competition law, ${ }^{56}$ perhaps a more interconnected approach can be seen with exploring the SGEI exception.

\section{CONCLUSION}

Given the political salience, if not legal effect, of Article 168(7) TFEU, it is unsurprising that COVID-I 9 response proposals should be shaped around this, suggesting that Member States have a significant role to play in a European Health Union alongside other measures, inter alia, based on the public health aspects of Article 168 TFEU. A closer reading of Article 168(7) TFEU has highlighted questions of defining "national health policy" relative to Union activities, how longer-term continuity of non-COVID-19-related healthcare may offer a different perspective on Member State-Union interaction, and how wider Union fiscal policy in particular may shape practical consequences for Member State responsibility for their healthcare systems, suggesting that differentiated approaches may lead to paradoxes of Member States having markedly divergent responses to the public health and economic effects of COVID-19. ${ }^{57}$

Corona crisis", March 2020. https://ec.europa.eu/competition/ecn/202003_joint-statement_ecn_coronacrisis.pdf.

Communication from the Commission, Temporary Framework for State Aid Measures to Support the Economy in the current COVID-19 Outbreak.

https://ec.europa.eu/competition/state_aid/what is new/TF_consolidated_version_amended_3 april_ 8 may and 29 june 2020 en.pdf.

${ }^{54}$ Indeed, the question of the future of state aid is considered by Stefan and Biondi in this issue.

${ }^{55}$ De Ruijter and Greer, supra note 7.

${ }^{56}$ In reflection of recent Court of Justice case law, specifically Case C-74/16 Congregación de Escuelas Pías Provincia Betania, 27 June 2017, ECLI:EU:C:2017:496, which enabled the development of a "three-prong test" by van de Gronden based on solidarity to determine applicability of Union competition law. See J.W. van de Gronden, "Services of general interest and the concept of undertaking: does EU competition law apply?" (2018) World Competition 4I, 197-224. This test has recently been analysed in the healthcare context for the first time - see J.W. van de Gronden and M. Guy, "The role of EU competition law in healthcare and the "undertaking" concept", (2020) Health Economics, Policy and Law, FirstView.

${ }^{57}$ For example, in April 2020, Greece was considered a success story in terms of healthcare, but likely to be the worst-hit Member State in terms of the economic downturn of the pandemic. V. Hatzopolous, "Taming the COVID-19, not the GDPR: the case of Greece", https://blogdroiteuropeen.com/2020/07/04/taming-thecovid-19-not-the-gdpr-the-case-of-greece-by-vassilis-hatzopoulos/ 